\title{
Climate Change and Brazil's coastal zone: socio-environmental vulnerabilities and action strategies
}

Mudanças Climáticas e a zona costeira do Brasil: vulnerabilidades socioambientais e estratégias de ação

Paulo Horta

Patrícia F. Pinho ${ }^{b}$

Lidiane Gouvêa $^{c}$

Guido Grimaldid

Giovanna Destrie

Carolina Melissa Mueller

Lyllyan Rocha ${ }^{9}$

José Bonomi Barufi

Leonardo Rorigi

Jorge Assis

Letícia Cotrim da Cunhak

a Federal University of Santa Catarina, Laboratory of Phycology, Center for Biological Sciences, Federal University of Santa Catarina, Florianópolis, SC, Brazil

E-mail: paulo.horta@ufsc.br

${ }^{b}$ Institute for Advanced Studies, University of São Paulo (USP), São Paulo, SP, Brazil E-mail:pinhopati@gmail.com

' Graduate Program in Ecology, Federal University of Santa Catarina, Florianópolis, SC, Brazil E-mail: lidianegouv@gmail.com

${ }^{d}$ Graduate Program in Ecology, Federal University of Santa Catarina, Florianópolis, SC, Brazil E-mail: guidogrimaldi@gmail.com

e Graduate Program in Oceanography, Federal University of Santa Catarina, Florianópolis, SC, Brazil E-mail: giovannanddestri@gmail.com

${ }^{f}$ Federal University of Santa Catarina, Laboratory of Phycology, Center for Biological Sciences, Federal University of Santa Catarina, Florianópolis, SC, Brazil E-mail: carolinammueller@gmail.com 
${ }^{g}$ Graduate Program in Oceanography, Federal University of Santa Catarina, Florianópolis, SC, Brazil E-mail: lyllyrocha20@gmail.com

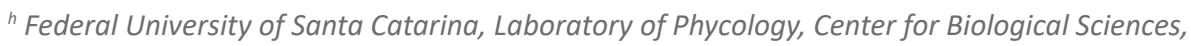
Federal University of Santa Catarina, Florianópolis, SC, Brazil E-mail: jose.bonomi@gmail.com

' Federal University of Santa Catarina, Laboratory of Phycology, Center for Biological Sciences, Federal University of Santa Catarina, Florianópolis, SC, Brazil E-mail: leororig@gmail.com

j Center for Marine Sciences, University of Algarve, Portugal E-mail: jorgemfa@gmail.com

${ }^{k}$ Graduate Program in Oceanography/ Oceanography College, Rio de Janeiro State University (UERJ), Maracanã Campus, Rio de Janeiro, RJ, Brazil E-mail: Icotrim@uerj.br

Data and results presented in this article were developed under the project of the "Fourth National Communication and Biennial Update Reports of Brazil to the Climate Convention", coordinated by the Ministry of Science, Technology and Innovations, with the support of the United Nations Development Programme and resources of the Global Environment Facility, to which we offer our thanks.

\begin{abstract}
The coastal zone, where most of the Brazilian population lives, plays a central role for discussing vulnerability and adaptation strategies to climate change. Besides saltmarshes, mangroves and coral reefs, this region also presents seagrass beds, macroalgae and rhodolith beds, forming underwater forests, which are key habitats for services such as biodiversity conservation, $\mathrm{O}_{2}$ production, and absorption of part of the $\mathrm{CO}_{2}$ from the atmosphere. Science endorses that ocean warming and acidification, sea level rise, biological invasions and their interactions with pollution, overfishing, and other stressors undermine the structure and functioning of these ecosystems, thus increasing the region's socio-environmental vulnerability. Ecosystem conservation, management and potential bioremediation/restoration using science-based solutions must be prioritized in order to reduce the vulnerability of coastal communities and the ocean.
\end{abstract}

Keywords: Blue Amazon. Biodiversity. Global stressors. Ocean warming. Ocean acidification. Pollution.

\title{
Resumo
}

A zona costeira, região que concentra boa parte da população brasileira, exerce papel central para a discussão da vulnerabilidade e adaptação às mudanças climáticas. Além de marismas, manguezais e recifes de coral, nesta região encontramos bancos de gramas marinhas, de macroalgas e de rodolitos, que formam florestas submersas, habitats fundamentais para serviços como o de manutenção da biodiversidade, produção de $\mathrm{O}_{2}$ e absorção de parte do $\mathrm{CO}_{2}$ da atmosfera. A ciência reforça que o aquecimento e acidificação do oceano, a elevação do nível do mar, invasões biológicas e suas interações com a poluição, sobrepesca, entre outros estressores, comprometem a estrutura e o funcionamento destes ecossistemas, elevando a vulnerabilidade socioambiental da região. A conservação destes ecossistemas, seu manejo, eventual biorremediação/restauração, usando soluções baseadas em 
evidências cientificas, devem ser priorizadas para a redução da vulnerabilidade das comunidades costeiras e do oceano.

Palavras-chave: Amazônia Azul. Biodiversidade. Estressores Globais. Aquecimento do oceano. Acidificação do oceano. Poluição.

\section{INTRODUCTION}

The discussion on Brazil's vulnerabilities to climate change has thrived at national level, mainly the interactions of local stressors like pollution, deforestation and fires, which aggravate consequences for the biomes. However, little importance has been given to the coastal marine environment. Brazil has one of the world's longest coastlines $\left(\sim 9,000 \mathrm{~km}^{2}\right.$ ), and its exclusive economic zone (EEZ, a stretch from the coastline off to 200 nautical miles), known as Blue Amazon (Figure 1), is equivalent to the surface of the Legal Amazon area, comprising some 3.5 million km² (PRADO et al., 2015a; KERR et al., 2016b; GERHARDINGER et al., 2018)as in many other tropical countries, coastal communities have been dealing with a complex dynamics of change, mostly related to the degradation of ecosystems, growing tourism and changing government policies, with consequences for natural resources conservation and management. Understanding how these communities are dealing with such change and the tradeoffs provide insights for building resilience. In this paper, we investigate how a Caiçara community (traditional group of mixed heritage.

The coastal region comprises remnants of the Atlantic Forest, parts of the Caatinga and the Amazon biomes (MARRONI e ASMUS, 2013), and some $60 \%$ of the country's urban population. This corresponds to $25 \%$ of the total population, concentrated in $4 \%$ of the national territory's area, with high demand for energy, food, water and housing (Figure 1). Population density, poor spatial planning and inadequate basic sanitation have an impact on the environment (HALPERN et al., 2015), changing the landscape and leading to air, soil and, especially, runoff pollution, thus impairing coastal environments' health (ELFES et al., 2014; HALPERN, 2020).

Like forests, the ocean acts as an annual sink of about $25 \%$ of $\mathrm{CO}_{2}$ anthropogenic emissions, thus regulating the climate, which in turn benefits the population and the economy at several levels (WEATHERDON et al., 2016; COPERTINO et al., 2017; BERGSTROM et al., 2019). Besides mangroves and coral reefs, coastal regions also present seagrass beds, saltmarshes, macroalgae and rhodolith beds, forming underwater forests, rich and abundant biodiversity niches.

These ecosystem services, in addition to mitigating climate change and ocean acidification, also protect the coast from erosion. Saltmarshes, mangroves (SCHAEFFER-NOVELLI et al., 2016) and seagrass beds (COPERTINO et al., 2016) have been historically present in the culture of traditional communities that live along Brazil's coastline. These environments also function as nurseries for a variety of marine organisms, contributing for the maintenance of economically and culturally important species.

The ocean and coastal zones' ecosystem services, essential for climate balance, food, energy, water and socio-cultural heritage securities, were emphasized in the Paris Agreement in 2015. In addition, conservation and good management of these services may represent solutions to problems related to energy demand and health, enabling alternatives to mitigate greenhouse gas emissions (GOUVÊA et al., 2020). The growing environmental conflicts caused by timber trade, agriculture, and mining compromise the services of the main terrestrial biomes (Pantanal, Cerrado and Amazon). Therefore, it is also necessary to highlight the vulnerabilities and threats experienced by Brazilian marine ecosystems. 


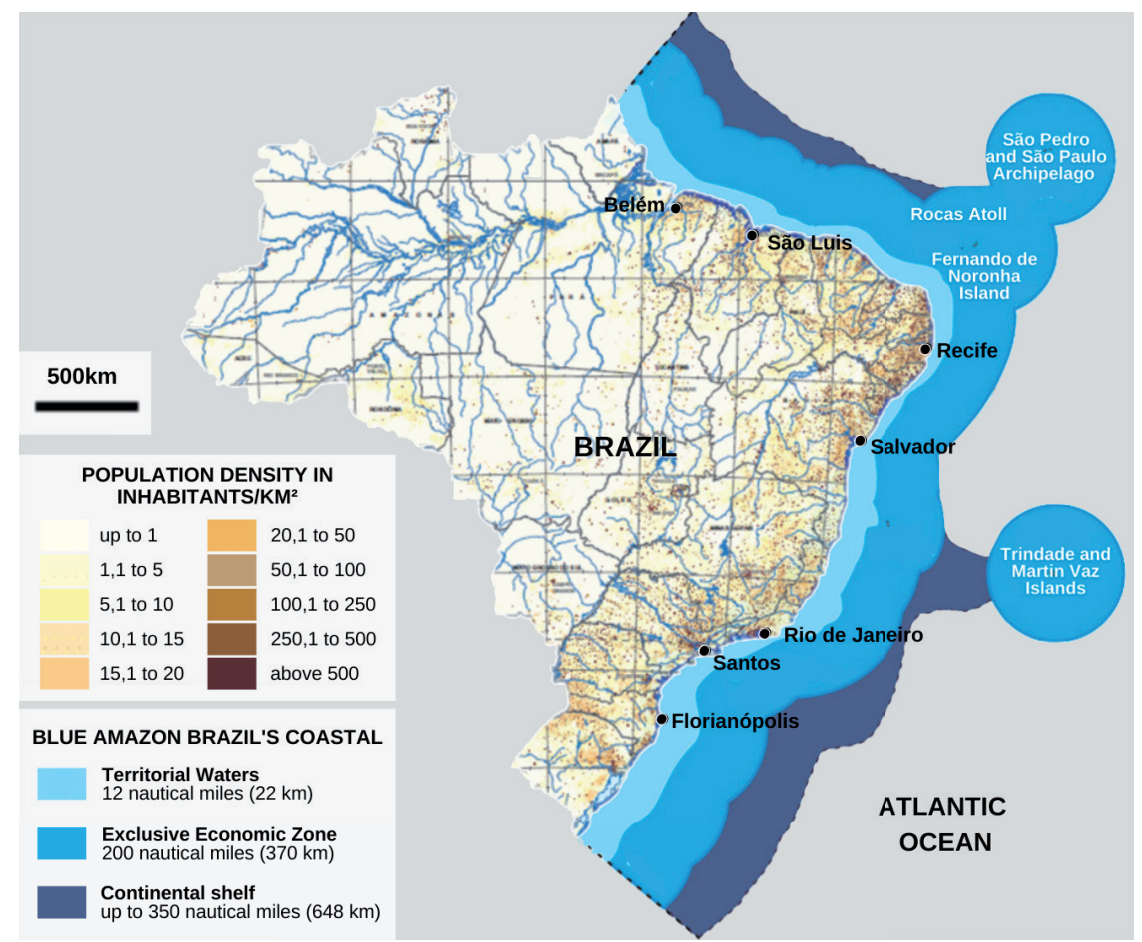

Figure 1 | Map of Brazilian population density represented from dark brown (most densely populated areas) to white. Light blue represents the territorial sea, turquoise represents the Exclusive Economic Zone (EEZ), navy blue represents the continental shelf, which make up the so-called Blue Amazon (Gerhardinger et al. 2018).

\section{Source: Census IBGE 2010.}

Marine forests species decline has been reported on the Brazilian coast and attributed to urbanization (MARTINS et al., 2012) or other environmental stressors (GORMAN et al., 2020). Due to its extension and varied environmental conditions, the Brazilian coast is a good model to understand species displacement processes and to predict the consequences of climate change, especially those related to vulnerable communities' adaptation to transition regions, like the ones around the state of Santa Catarina (KRONIK et al., 2010; ZANETTI et al., 2016; BUSTAMANTE et al., 2019).

Some macroalgae genera are part of the structure of underwater forests in biogenic or rocky, tropical, and warm temperate reef systems (SPALDING et al., 2007), such as the Sargassum genus. In the Brazilian coast, it is found as benthic from the intertidal zone to great depths, but also include pelagic forms, which constitute floating masses (Sissini et al., 2017). Among the dominant Sargassum spp. morphologies, arborescent leaves and filamentous turfs algae stand out. These primary producers dominate $80 \%$ of the area of Brazilian submerged reefs with coverage ranging from $60 \%$ to almost $100 \%$ of the available substrate (AUED et al., 2018).

Underwater forests over consolidated seabeds dominated by Sargassum spp. have more threedimensional complexity and spatial heterogeneity, playing an important ecological role in the composition and distribution of communities (JACOBUCCI and LEITE, 2002; GIANNI et al., 2013, MANSILLA and PEREIRA, 1998; SZÉCHY and PAULA, 2000; SZÉCHY et al., 2006; FIGUEIREDO and TÂMEGA, 2007).

Recent studies highlight that macroalgae are becoming less abundant or even disappearing from some areas of the ocean (TEAGLE et al., 2017), including in Brazil (GORMAN et al., 2020). Warming and acidification may compromise the oceans' life cycle, reducing their resistance, mainly if associated to coastal pollution (ARAÚJO et al., 2015; MARTINS et al., 2018). Populations that experience to extreme temperatures above optimal eco-physiological conditions, like the Sargassum spp. populations on the coast of the state of Santa Catarina, would represent the most vulnerable contingent against environmental unbalances (ARAÚJO et al., 2011; VIEJO et al., 2011). The physiological stress caused 
by temperatures outside the ideal range leads to variations in enzymatic processes, cell damage, and death (EGGERT et al., 2012). These damages and the reallocation of physiological resources for protection and repair may affect growth and development and may cause individual mortality or even the local or regional population's extinction (DAVISON and PEARSON, 1996).

This study presents: i) a synthesis and an analysis based on the peer-reviewed bibliography of Brazilian efforts to describe the importance of coastal environments, their ecosystem services, and how these areas may respond to climate change; and ii) statistical modeling to discuss the impacts of ocean warming and acidification on the potential distribution of macroalgae forests dominated by the genus Sargassum spp., which are widely distributed along the Brazilian coast. Thus, this article presents the background for discussions related to environmental stressors impacts on niche adequacy for these organisms on the Brazilian coast. Considering that climate impacts interact with pollution, deforestation, use of pesticides or overfishing, this article also discusses possible solutions for the development of management tools that promote the restoration or conservation of balanced and healthy ecosystems.

\section{MATERIAL AND METHODS}

\subsection{BIBLIOMETRICS}

The SCOPUS, SCIENCE DIRECT and WEB OF SCIENCE databases, available at the CAPES publications portal, were used as sources of information and basis for bibliographic searches. Scientific articles were selected according to the use of the following key words: "Costal zone", "Climate change", "Changing oceans", "Global stressor", "Sea level", "Sea level rise", "Global warming", "Ocean warming", "Marine heatwaves", "Heatwaves", "Storms", “Ocean acidification”, "Mangrove”, “Estuaries”, “Rockshore”, "Seagrass", "Seaweed”, "Macroalgae", "Sargassum", "Sandy Beach", "Coral Reef", "Rhodolith" and "Brazil". After a search for duplications and reference inadequacy for lack of coherence to the theme of the 4th National Communication on Climate Change, the works were exported to Biblioshiny for an analysis, by Bibliometrix 4.0 (SHI 2019), of metadata, global quotation, authors, and theme. The effort is represented by a word cloud that sums up the central aspects of the Brazilian academy's efforts to study climate change in the Blue Amazon.

\subsection{POTENTIAL DISTRIBUTION MODELLING}

Considering the need to understand climate change impacts on underwater forests and the lack of information about other species distribution, this article decided to assess suitability model for the genus Sargassum spp. for being among the most abundant and frequent on the coast, representing underwater forests (GORMAN et al., 2020).

The distribution analysis at present and future scenarios considered Representative Concentration Pathways (RCPs), and benthic environmental variables that are relevant to Sargassum spp: minimum and maximum temperature $\left({ }^{\circ} \mathrm{C}\right)$ and minimum of irradiance $\left(E \cdot \mathrm{m}^{-2} \cdot \mathrm{dia}^{-1}\right)$, salinity (pss), nitrate, and phosphate $\left(\mu \mathrm{mol} . \mathrm{m}^{-3}\right)$, available in the Bio-ORACLE Database (TYBERGHEIN et al., 2012; ASSIS et al., 2017). Considering the known vertical distribution of benthic species of Sargassum,spp. the maximum depth of $100 \mathrm{~m}$ was defined as a limit, using a bathymetric data set, with spatial resolution of $30 \mathrm{arcmin}$ ( 9,2 km at the equator). Besides the environmental variables at current conditions (2000-2017), environmental conditions for the 2090-2100 period were also assessed in the RCP 2.6 and RCP 8.5 scenarios. RCP 2.6 represents a high mitigation scenario in which mean temperature increases by $2^{\circ} \mathrm{C}$ above pre-industrial levels, and RCP 8.5 is a scenario with warming of up to $4,9^{\circ} \mathrm{C}$ (TIGNOR et al., 2018). 


\subsection{PRESENCE/PSEUDOABSENCES DATA FOR POTENTIAL DISTRIBUTION MODELLING}

Georeferenced presence data for the genus Sargassum were sourced from the Global Biodiversity Information Facility online database (GBIF, 2018), and by the available literature. The data was approached according to Segurado et al. (2006), Cerasoli et al. (2017) and the models based on machine-learning algorithm Boosted Regression Trees (BRT) performed according to ELITH et al., (2008). Analyses were conducted in R (R Development Core Team, 2016) RStudio v.3.6.6 (Team, R. 2016). All maps were edited in QGIS (QGIS Development Team, R. 2019).

\section{Outcomes and Discussion}

\subsection{BIBLIOMETRICS}

A total of 234 bibliographic references were selected to build the national scenario of available Brazilian climate change impact studies on marine and coastal zones. Studies on this subject appeared in 1992 and increased in 2010 (supplementary material 1). Among the efforts of the past few decades, there are biogeochemistry studies related to the ocean acidification process and its impact on $\mathrm{pH}$ variation and total alkalinity, in addition to work related to sea level rise and its socio-environmental and economic impacts. $\mathrm{CO}_{2}$ emissions are recognized as a central topic, and the direct or indirect cause of many impacts and alterations in organism biology, or even in community and ecosystems ecology or cities and regions vulnerability (Figure 2 ).

Coastal environments were evaluated under different approaches, but used variables related to climate change and their interactions with local stressors. Recently, usually observed biodiversity and ecological interactions have been revisited within this context, with focus on sandy beaches (AMARAL et al. 2016), rocky shores (COUTINHO et al., 2016), seagrass beds (COPERTINO et al., 2016), mangroves and other estuarine formations (SCHAEFFER-NOVELLI et al., 2016; BERNARDINO et al., 2016), coral reefs (LEÃO et al., 2016), and Rhodolith beds (HORTA et al., 2016).

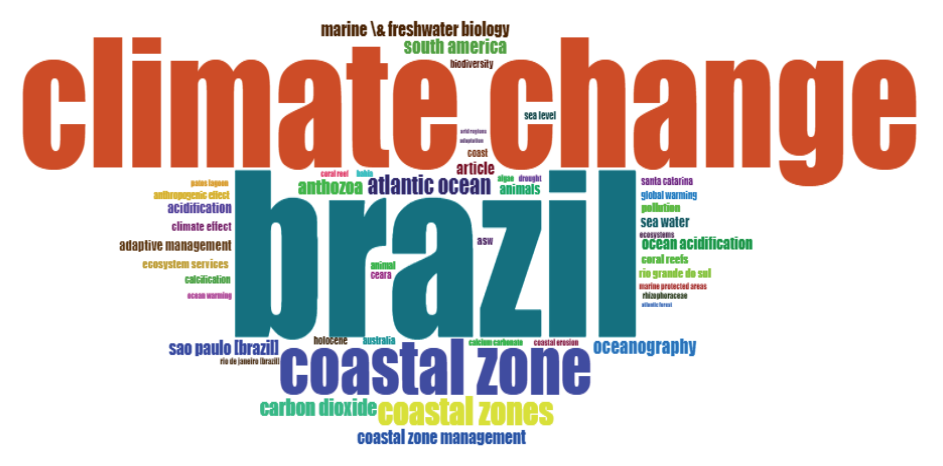

Figure 2 | Word cloud structured from a bibliographic review of aspects of climate change impacts and ocean acidification in the Blue Amazon. \}

ource: produced from the Biblioshiny program (2020).

The efforts made by the Brazilian academy and partners endorse, with various evidence, that climatechange-related factors (warming and acidification) or local stressors (pollution and overfishing), and their interactions, threaten the balance of these coastal marine ecosystems, and their products and services. Studies report on physiological alterations in the fauna (as in BARROS et al.,2017) and marine flora (as in SCHERNER et al., 2012; GOUVÊA et al., 2017), in addition to focusing on the importance of these ecosystems for the coastline stability against climate change (ELLIFF and SILVA, 2017). 
Notwithstanding the synthesis on climate change produced by the Brazilian Research Network on Global Climate Change and the Brazilian Ocean Acidification Network (KERR et al. 2016), other studies at national level mapping the presence of stressors in mining (MAGRIS et al., 2018), coastal pollution and fisheries (MAGRIS et al., 2019), biological invasions (KOERICH et al., 2020) or even global warming (MAGRIS et al., 2020) are scarce. These efforts are relevant to raise awareness about the severity of the problem and its national extent.

\subsection{POTENTIAL DISTRIBUTION MODELLING}

Potential distribution model outputs using RCP 2.6 and RCP 8.5 scenarios confirm niche loss and changes in the occurrence of Sargassum spp. (GORMAN et al., 2020) (SCHERNER et al., 2013). This suggests that even species with tropical affinities may experience losses at low latitudes and move south by 2100 (Fig. 3). The changes to the south do not seem to overcome or compensate for the losses in the distribution of Sargassum that may occur in the north. Moreover, despite minimum variations under low emission scenarios (RCP 2.6), there has been change in the potential distribution in the northern region of the country (Fig.3b). Distribution models showed high performance (True skill statistics-TSS 0.88 , and receiver operating characteristic curve- AUC 0.94) and correspond to the known distribution of the genus (Fig. 3). The environmental variables that best explain the potential distribution are light, salinity, and temperature (maximum and minimum), with relative influence above 15\% (Fig. 4).
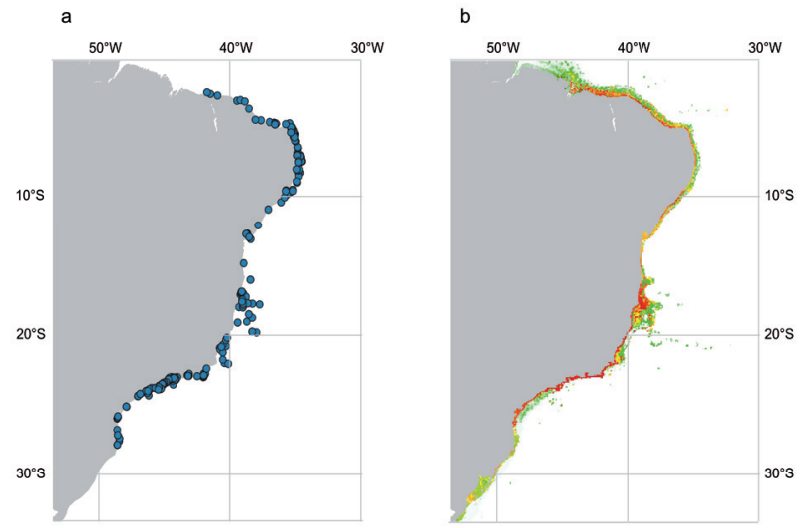

d
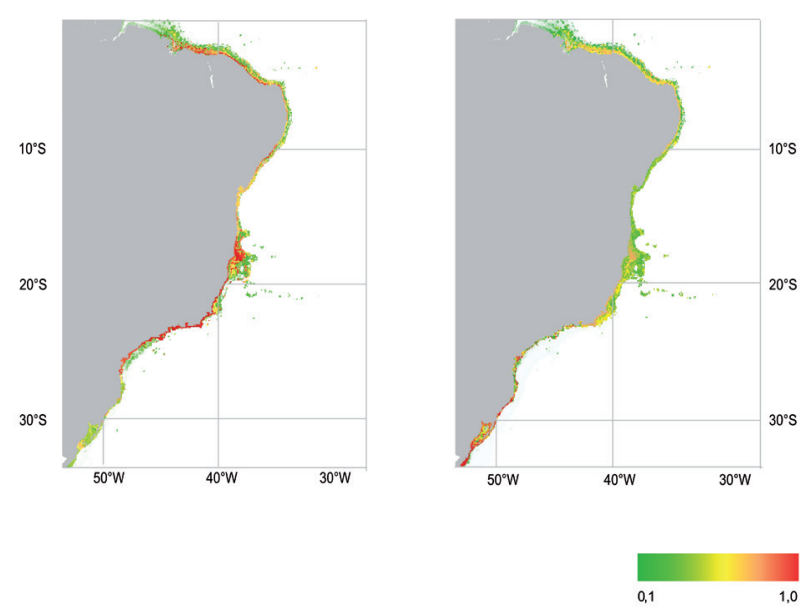

Figure 3 | Projections of the potential distribution of genus Sargassum, according to the occurrences (blue circles) on the Brazilian coast (a) considering the current scenario and predictive models generated from scenarios (b), RCP 2.6 of moderate emissions (c) and the most pessimistic scenario RCP 8.5 (d) for 2100 . The green to red scale represents niche suitability (low (0.1) to high (1.0), respectively). 


\section{Environmental variable $\quad$ Relative contribution (\%) Threshold}

\begin{tabular}{|c|c|}
\hline Light $\left(E \cdot m^{-2} \cdot\right.$ day $\left.^{-1}\right)$ & 32 \\
\hline Salinity (PSS) & 35 \\
\hline Max Temp $\left({ }^{\circ} \mathrm{C}\right)$ & 29 \\
\hline Min Temp $\left({ }^{\circ} \mathrm{C}\right)$ & 17 \\
\hline Nitrate $\left(\mu \mathrm{mol} \cdot \mathrm{m}^{-3}\right)$ & 0.1 \\
\hline Phosphate $\left(\mu \mathrm{mol} . \mathrm{m}^{-3}\right)$ & 0.01 \\
\hline
\end{tabular}

Figure 4 | Environmental variable, Relative contribution (\%) and threshold used to potential distribution modelling of benthic Sargassum. Dotted line represents contributions of 5\%.

\section{Source: Elaborated by the authors.}

The tropicalization observed at higher latitudes, which would increase niche suitability along the warm temperate coast, is not accompanied by availability of abundant consolidated substrate to shelter quantitatively representative populations. Studies based on temperature, salinity, and irradiance limits for Sargassum species correspond to the thresholds inferred by our models, with tolerance ranges from $18^{\circ} \mathrm{C}$ to $30^{\circ} \mathrm{C}$, salinity $>20$ and irradiance of $9.2-184 \mathrm{E} \cdot \mathrm{m}^{-2} \cdot$ day $^{-1}$ (HANISAK and SAMUEL, 1987, SCHERNER, et al. 2012, Ll et al. 2019).

The absence of rocky shores along the coast of the state of Rio Grande do Sul must be taken into consideration when discussing refugia availability (ADDIS et al., 2016, AINSWORTH et al., 2020) to shelter fauna and flora that have been losing niche in tropical environments due to climate change and other stressors. Biomass losses of these algae by $52 \%$ have been observed since the 1980 s on the southeastern coast of Brazil. This indicates that these ecosystems are losing health, highlighting the need for the urgent implementation of management systems to reduce stressors' impacts (GORMAN et al., 2020).

Marine heatwaves have increased in frequency and area in different regions, such as the Indo-Pacific Ocean (BENTHUYSEN et al., 2018), in the Mediterranean Sea (DARMARAKI et al., 2019) and in southern and northern Atlantic Ocean (GOUVÊA et al., 2017; OLIVER et al., 2018), inducing loss of marine forests. Moreover, a recent study has shown that two marine forests forming species (Sargassum fallax and Scytothalia dorycarpa) lost from $30 \%$ to $65 \%$ of their mean genetic diversity due to populational decline when exposed to a heatwave event (GURGEL et al., 2020). As projected warming trends continue during the $21^{\text {st }}$ century (HIRAISHI et al., 2014), additional large-scale distribution trends of algae communities are expected (JUETERBOCK et al., 2013). Temperature variations, like the ones induced by marine heatwaves, determine the eco-physiological performance of marine organisms (EGGERT, 2012), causing changes in communities' structure and function (LAURIE, 1990).

In the past two decades, the species dispersal rate has increased significantly in response to anthropogenic environmental changes, displacing tropical species towards higher latitudes (CHEN et al., 2011). The consequences of this tropicalization in the composition and structure of coastal ecosystem depend on complex scenarios that need to be clarified by long-term studies and with simulations of environmental variability with utmost realism. Tropical algae species, seagrass or even coral reefs may become dominant in warm temperate environments. These alterations in availability and energy flows must be considered in conservation and management strategies to minimize risks, including a discussion about the ecosystem's socio-environmental and ethical aspects (VÉRGES et al., 2019). 
When the distribution of key ecosystems for coastal resilience is mapped, they are seen as irreplaceable due to their role for biodiversity (COPERTINO et al., 2017), climate (BERGSTROM et al., 2019) and fishing stocks regulators (WEATHERDON et al., 2016), albeit under threat of multiple stressors in the Brazilian EEZ (MAGRIS et al., 2020) (Figure 4).

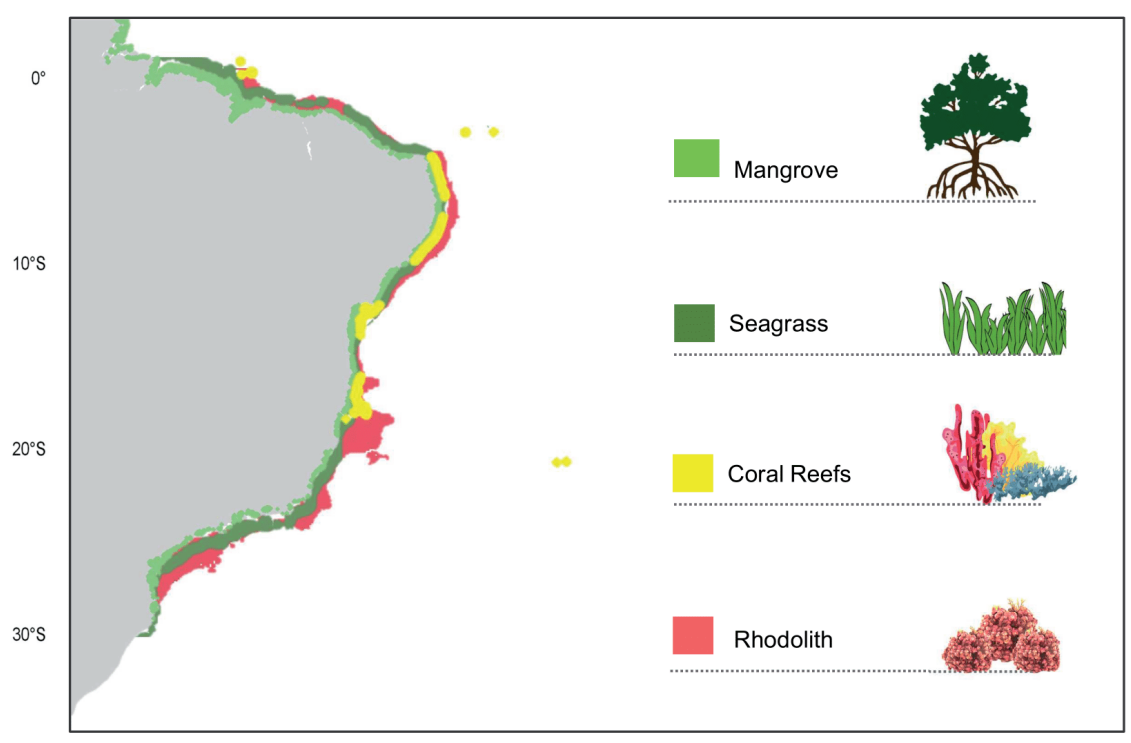

Figure 5 | Marine/coastal ecosystems distribution along the Brazilian EEZ whose physiognomy is determined by early-stage engineering species (mangroves (light green), seagrass (dark green), coral reefs (yellow) and rhodolith (pink).

Sources: http://gratispng.com; http://data.unep-wcmc.org; Giri et al. (2011), Carvalho et al. (2020) and Horta et al. (2016).

Mangroves, saltmarshes and seagrass beds are known as "blue carbon" deposits, where $\mathrm{CO}_{2}$ is stored in the form of organic material on the substrate sediments and biomass. Like macroalgae, during photosynthesis, these plants absorb large amounts of $\mathrm{CO}_{2}$ dissolved in water, thus raising the $\mathrm{pH}$ of water around the plant. This role as carbon sink helps mitigate the damage caused by sea acidification to reef ecosystems and calcifying species. The daily $\mathrm{CO}_{2}$ absorption by these primary producers may represent a solution and local adaptation for activities such as shellfish aquaculture, or in situ conservation of calcifying organisms, as these primary producers may mitigate acidification effects (BERGSTROM et al., 2019).

Notwithstanding the adaptive capacity of many species, it is observed that climate change impacts on the ocean biota, and warming, sea level rise, and acidification lead to the loss of biogenic reefs, mangroves, algae and seagrass beds (OPPENHEIMER et al., 2014; CRAMER et al., 2015; MAGALHÃES et al., 2020). Likewise, failing to intervene on human behavior feed a vicious cycle that compromises the ocean's ability to contribute to climate regulation (HORTA et al., 2018), as well as interactions and interdependencies of continental ecosystems (LEYBA et al., 2019; MARENGO et al., 2019).

It is important to highlight that rainfall variability changes the continental runoff both qualitatively and quantitatively, affecting the coastal region. Coastal salinity decrease associated to rainfall increase may be linked to the depletion of underwater forests of Sargassum (SCHERNER et al., 2012). Additionally, blooms of floating populations (GOUVÊA et al., 2020) might be related to fertilization river basins with nutrients derived from fertilizers, soil erosion and livestock activities (BUSTAMANTE et al., 2015).

Besides climate change, varied sources of pollution, overfishing, among other aspects related to the country's spatial planning, socioeconomic dynamic and governance have caused services loss and ocean and coastal zone vulnerability, increasing erosion and compromising the quality of life and income of the traditional populations that live in those areas (REYER et al., 2017; HORTA et al., 2012; COPERTINO et al., 2017; GERHARDINGER et al., 2018). 
There is an intersection of the most distinct climate change impacts on socially vulnerable areas in the country's coastal zones. Poverty and socioeconomic inequality encompass both the urban population and traditional peoples, who fully depend on coastal zones and the ocean for their way of life and economy (SARAIVA et al., 2018). Socio-environmental data show that $82 \%$ of Brazilian coastal municipalities have less than half of their households connected to the sewage network, implying the irregular dumping of these wastes in courses that flow into the sea. The coastal population's average income does not exceed 6 minimum wages and $27 \%$ of these municipalities have an average income of less than one minimum wage, around US\$200,00 (IBGE, 2010).

From that perspective, fisheries and other water resources may be compromised by overexploitation and inadequate management, in addition to climate change threats. Climate impacts on fisheries resources are caused by an increase in air and ocean temperature and sea level rise. Combined to acidification, warming and local stressors cause coral reef losses, which, in turn, leads to coastal productivity loss and shortages of various natural resources (CYBULSKI et al., 2020). It is estimated that $1 \%$ loss of coral global coverage would lead to $3.8 \%$ economic loss associated with the recreational and commercial value of reef coverage equivalent to US\$ 3.95 to US\$23.78 billion annually (CHEN et al., 2015).

Despite the high, and so far underestimated economic losses for Brazil (MARTINS e GASALLA, 2018), climate change impacts have led to cultural losses such as altering and compromising the way of life, deaths linked to catastrophes caused by extreme events, as well as forced migrations from the place of origin associated with coastal erosion. These aspects are not quantified in the economic valuing metric, but lead to significant damage (HOEGH-GULDBERG et al., 2014; PRADO et al., 2015b). These non-economic losses to the population compromise the next generations and the ability to build a dignified, safe and sustainable future (ROY et al., 2018).

Evidence show that limiting global warming to $1.5^{\circ} \mathrm{C}$ above pre-industrial levels is pivotal for the survival of coral reef systems, since a $2^{\circ} \mathrm{C}$ mean global warming combined with acidification lead to severe biodiversity losses (ROY et al., 2018). This stresses the urgency of mitigation, restoration and socioeconomic adaptation actions (BERGSTROM et al., 2019). The loss of calcification capacity by these organisms, observed in combined scenarios of warming, acidification, and coastal pollution, might increase the losses of ecosystem services. If, on one hand, heating may compromise calcification by up to $50 \%$, pollution may reduce these building organisms primary production by 90 to $100 \%$. (SCHUBERT et al., 2019).

Considering the biogenic reefs and rhodolith beds from the Amazon River mouth to off the coast of Santa Catarina state (CARVALHO et al., 2020), the exposure of these organisms to extreme temperature conditions and lower $\mathrm{pH}$ may lead to the loss of $80 \%$ of the carbonate structure, thus compromising the entire ecosystem (MUÑOZ et al., 2018). Rhodolith beds are not fully investigated, but due to their ecological and evolutionary importance, deserve greater attention in public policies for conservation and management. These organisms occupy some 230 thousand $\mathrm{km}^{2}$ along the EEZ, which corresponds to a carbonate deposit of about 2.1011-ton C, therefore being a long-term carbon reservoir (CARVALHO et al., 2020).

\section{RELEVANT SCIENTIFIC INITIATIVES IN PUBLIC POLICIES FOR OCEANS AND COASTAL ZONES}

Some Brazilian scientific initiatives have stood out in highlighting the impacts and vulnerabilities of coastal areas and the ocean due to climate change and other stressors. In this regard, the Brazilian Research Network on Global Climate Change and its sub-networks on Oceans and Coastal Zones, the BrOA Network (the Brazilian Ocean Acidification Network), the Sisbiota Network, marine-coastal INCTs and the PELD program are noteworthy. All these efforts have been consolidated and contributed to the understanding on the impacts of climate change and ocean acidification on different ecosystems and 
groups of organisms. The academic maturity process observed in Brazil is the direct result of investments made in infrastructure and availability of scholarships, especially for post-graduate studies, which were particularly significant by 2015 (ROSSI et al., 2019, MACÁRIO e REIS, 2020).

In this scenario, the Brazilian Research Network on Global Climate Change stands out for its national scope, involving dozens of research groups at universities and institutes, distributed in sub-networks in all regions of the country and working on studies on impacts, adaptation and vulnerabilities for agriculture and forestry, water resources, biodiversity and ecosystems, coastal zones, cities, economy, renewable energy, and health. The Coastal Zones sub-network and its coastal monitoring associate (the REBENTOS-Coastal Benthic Habitats Monitoring Network) is an inter-disciplinary, inter-institutional research network, with regional representativeness, encompassing the areas of coastal geomorphology, physical oceanography, biogeochemistry, biological oceanography, marine and socioeconomic ecology.

The BrOA network acts on topics related to ocean acidification, from observation studies that include coastal areas, to tests with organisms and numerical modeling. The BrOA network currently works in a self-organized way, with no funding, and is registered as a research group under CNPq, with about 40 researchers distributed in the country. Since its foundation, it has published reports and scientific articles to promote knowledge about ocean acidification, being recognized as a partner by the General Coordination of Geosciences, Ocean, and Antarctica of the MCTI.

These networks articulate and add efforts to projects related to long-term ecological programs that have already been consolidated or are about to be consolidated, which promote the monitoring of the country's different aspects and ecosystems. Considering the Blue Amazon extension, it is pivotal to consider the need to consolidate, broaden and engage these projects, groups and networks so that results are more robust and disclosed at the national level (Figure 5). 

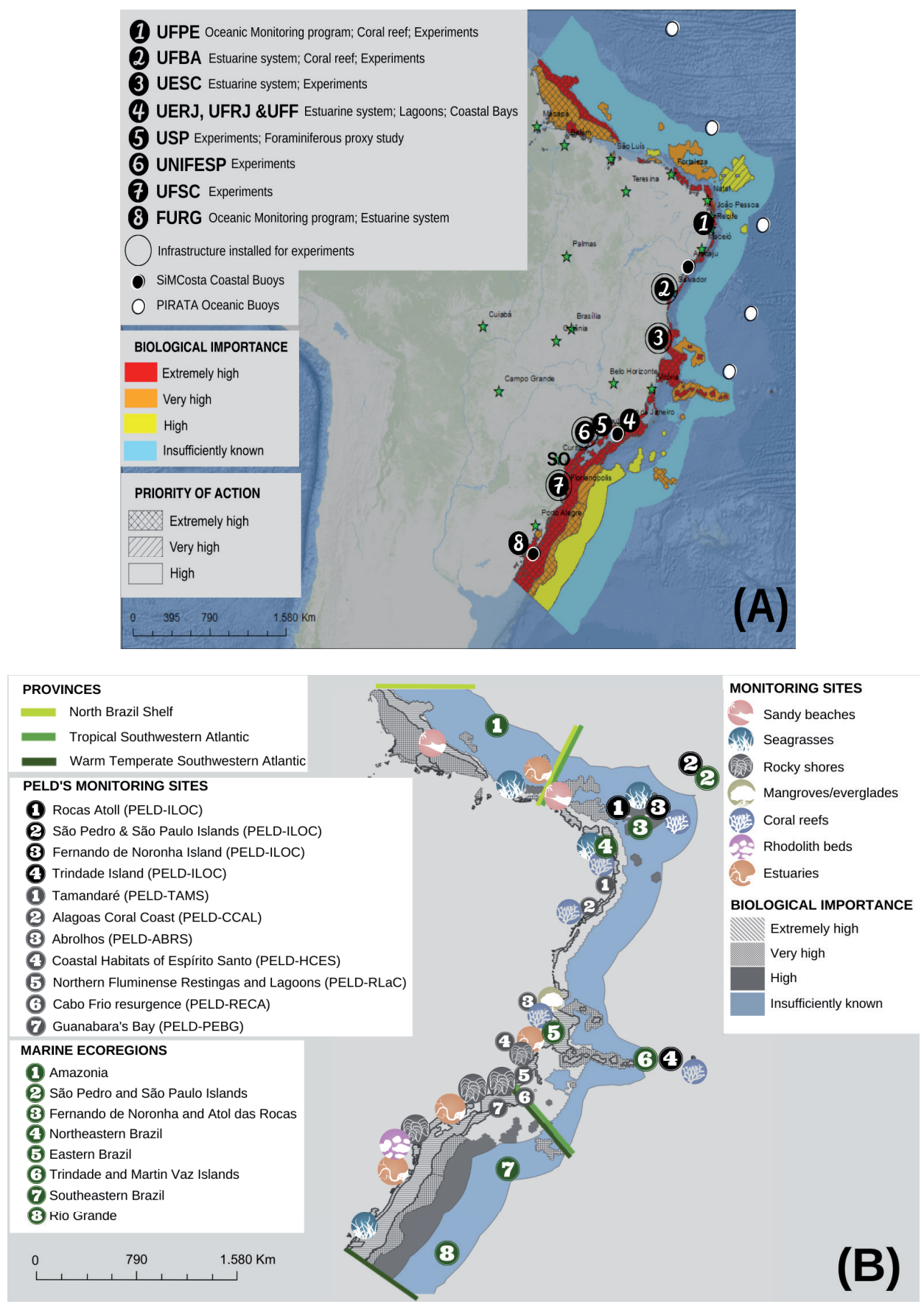

Figure 6 | Scientific networks monitoring Brazilian marine biodiversity. (A) Numbered circles indicate regional groups within the network, organized by institution, and the special arrangement of their areas of expertise: experiments, estuaries, coastal or oceanic observation and monitoring (buoys and/or oceanographic cruises). Dark circles indicate the SiMCosta buoy network, and the white circles indicate the Prediction and Research Moored Array in the Atlantic buoys. Highlighted in warmer colors, areas of greater biological importance and in the different filling patterns, the different degrees of priority action stand out; (B) Biogeographic provinces and marine ecoregions with emphasis on the biological importance and ecosystems monitored by REBENTOS and coastal marine PELD sites.

Sources: Spalding et al. 2007, Kerr et al. 2016, www.cnpq.br.

This set of institutions and the installed infrastructure are a strong ally for building impact adaptation and mitigation for coastal marine environments in the country. It is important to invest in maintaining and broadening these networks for the sustainable development and management of the country's coastal-marine environments. Academic knowledge and infrastructure must be articulated to the 
organized society, using traditional knowledge to jointly define priorities for action to tackle the problems experienced and projected for the future of the Brazilian coast (GRILLI et al., 2019).

The Brazilian coastal management process must be considered in an integrated way due to the major interdependency between the coastal/oceanic system and the continental runoff (GRILLI et al., 2019). An integrated management system must avoid or mitigate the negative consequences of accidents such as those in the municipality of Mariana, in the state of Minas Gerais, which resulted in priceless losses from a human and environmental point of view since its occurrence, in November 2015, to the present day (CARMO et al., 2017) and for different coastal environments (COSTA et al., 2019). This accident affected different environments and conservation units, impacting over 1 million Brazilians, with consequences on coastal systems up to $200 \mathrm{~km}$ south (MARTA-ALMEIDA et al., 2016) and even northwards the Rio Doce mouth to the Abrolhos reef system (MAGRIS et al., 2018; FERNANDES et al., 2016).

Considering the beginning of the UN Ocean Decade (2021-2030), it is necessary to effectively contribute to coastal sanitation and mitigation of problems related to climate change and pollution in the Blue Amazon. Management of aquatic ecosystems with high water quality remediation capacity and potential for generating goods and services such as atmospheric $\mathrm{CO}_{2}$ storage, such as macrophytes and macroalgae, reef environments, salt marshes, seagrass beds and rhodolith beds.

Respecting biogeography aspects particularities and the coast's latitudinal extension may lead to solutions based on scientific evidence to promote social development combined with ecological balance.

\section{CONCLUSION}

The national efforts made in the past decades have produced robust evidence of climate change impacts on the coastal zones and the risks they represent to the safety of coastal communities and marine ecosystems. Among global stressors, ocean warming, and acidification stand out. Local stressors include pollution and overfishing. These stressors impact on and compromise ecosystem products and services from mangroves, saltmarshes, reefs, seagrass beds, macroalgae and rhodolith beds.

Mapping the EEZ, its biodiversity and functioning, must guide integrated management actions, and discussions must value the particularities, vulnerabilities, resilience, climate refuges, high diversity environments and socio-environmental importance, considering the advancement of local and global threats. Concerted actions and the search for solutions based on scientific evidence must promote the balance of Brazil's coastal marine environments, accompanied by the unique health of the country's ocean and society' well-being.

\section{ACKNOWLEDGEMENTS}

This study was carried out with the support of grants from the Boticário Foundation, FAPESC- Research and Innovation Support Foundation of the State of Santa Catarina, Capes-Coordination for the Improvement of Higher Education Personnel, CNPq-Council of Scientifc and Technological Development, Petrobras Ambiental, REBENTOS-Coastal Benthic Habitats Monitoring Network, and ProspecMarSustainable Prospecting in Oceanic Islands: Biodiversity, Chemistry, Ecology and Biotecnology, Live Coral Network, REDEALGAS. The Portuguese Science and Technology Foundation (FCT) via FRH/BSAB/ 150485/2019, transitory norm DL57/2016/CP1361/CT0035, UIDB/04326/2020 project and PTDC/BIACBI/6515/2020.PAH thanks CAPES- Senior Visitor, CAPES-PrInt 310793 / 2018-01, CNPq-PVE 407365 / 2013-3, CNPq-Universal 426215 / 2016-8 and CNPq-PQ- 308537 / 2019-0. LCC thanks the UERJ/FAPERJ Pro-Science grant for the 2018-2021 period. 


\section{References}

ADDIS, D. T.; PATTERSON III, W. F.; DANCE, M. A. The potential for unreported artificial reefs to serve as refuges from fishing mortality for reef fishes. North American Journal of Fisheries Management, v. 36, n. 1, p. 131-139, 2016.

AINSWORTH, T. D.; HURD, C. L.; GATES, R. D.; BOYD, P. W. How do we overcome abrupt degradation of marine ecosystems and meet the challenge of heat waves and climate extremes? Global Change Biology, v. 26, n. 2, p. 343-354, 2020.

Amaral, A. C. Z.; Corte, G. N.; Denadai, M. R.; Colling, L. A.; Borzone, C.; Veloso, V.; ... \& Rosa, L. C. D. Brazilian sandy beaches: characteristics, ecosystem services, impacts, knowledge and priorities. Brazilian Journal of Oceanography, v. 64(SPE2), p. 5-16, 2016.

ARAÚJO, R.; SERRÃO, E. A.; SOUSA-PINTO, I.; ABERG, P. Phenotypic differentiation at southern limit borders: the case study of two fucoid macroalgal species with different life-history traits. Journal of Phycology, v. 47, n. 3, p. 451-462, abr. 2011. doi:10.1111/j.1529-8817.2011.00986.x.

ARAÚJO, R.; SERRÃO, E. A.; SOUSA-PINTO,I; ARENAS, F.; MONTEIRO, C.A.; TOTH, G., ÅBERG, P. Trade offs between life-history traits at range-edge and central locations. Journal of Phycology, v. 51, n. 4, p. 808-818, jun. 2015. doi:10.1111/jpy.12321.

ARAÚJO, M. E.; DE MATTOS, F. M. G.; DE MELO, F. P. L.; CHAVES, L. D. C. T.; FEITOSA, C. V.; LIPPI, D. L.;HACKRADT, F. C. F.; HACKRADT, C. W.; NUNES, J. L. S.; LEÃO, Z. M. A. N.; KIKUCHI, R. K. P.; JUNIOR, A. V. F.; PEREIRA, P. H. C.; MACEDO, C. H. R.; SAMPAIO, C. L. S.; FEITOSA, J. L. L. Diversity patterns of reef fish along the Brazilian tropical coast. Marine Environmental Research,v. 160, p. 105038, set. 2020.

ASSIS, J.; TYBERGHEIN, L.; BOSCH, S.; VERBRUGGEN, H.; SERRÃO, E. A.; DE CLERCK, O. Bio- ORACLE v20: Extending marine data layers for bioclimatic modelling. Global Ecology and Biogeography, v. 27, n. 3, p. 277-284, dez. 2017. doi:101111/geb12693.

AUED, A.W.; SMITH, F.; QUIMBAYO, J. P.; CANDIDO, D. V.; LONGO, G. O.; FERREIRA, C. E. L.; WITMAN, J. D.; FLOETER, S. R.; SEGAL, B. Large-scale patterns of benthic marine communities in the Brazilian Province. PloS one, v. $13, \mathrm{n}$. 6, p. e0198452, 2018.

Benthuysen, J. A.; Oliver, E. C. J.; Feng, M.; and Marshall, A. G. Extreme marine warming across tropical Australia during austral summer 2015-2016. J. Geophys. Res. Oceans. 123, 1301-1326. 2018. doi: 10.1002/2017JC013326

BERGSTROM, E.; SILVA, J.; MARTINS C.; HORTA, P. Seagrass can mitigate negative ocean acidification effects on calcifying algae. Scientific Reports, v. 9, n.1932, fev. 2019. doi: 10.1038/s41598-018-35670-3.

BERNARDINO, A. F.; PAgliOSA, P. R.; CHRISTOFOLETTI, R. A.; BARROS, F.; NETTO, S. A.; MUNIZ, P.; LANA, P. $D$. C. Benthic estuarine communities in Brazil: moving forward to long term studies to assess climate change impacts. Brazilian Journal of Oceanography, v. 64(SPE2), p. 81-96, 2016.

BARROS, L. F.; MARQUES, J. A.; DUARTE, G. A. S.; PEREIRA, C. M.; CALDERON, E. N.; CASTRO, C. B.; BIANCHINI, A. Copper effects on biomarkers associated with photosynthesis, oxidative status and calcification in the Brazilian coral Mussismilia harttii (Scleractinia, Mussidae). Marine Environmental Research, v. 130, p. 248-257, 2017.

BUStAMANTE, M. M., MARTINELLI, L. A., PÉREZ, T., RASSE, R., OMETTO, J. P. H., PACHECO, F. S. \& MARQUINA, $S$. Nitrogen management challenges in major watersheds of South America. Environmental Research Letters, 10(6), 065007, 2015.

BUSTAMANTE, M. M. et al. Tendências e impactos dos vetores de degradação e restauração da biodiversidade e serviços ecossistêmicos. In: SCARIOT A. et al. (eds). Plataforma Brasileira de Biodiversidade e Serviços Ecossistêmicos. 2018.

BUSTAMANTE, M. M. et al. Ecological restoration as a strategy for mitigating and adapting to climate change: lessons and challenges from Brazil. Mitigation and Adaptation Strategies for Global Change, v. 24, n. 7, p. 12491270, 2019. 
CARMO, F. F., KAMINO, L. H. Y., JUNIOR, R. T., DE CAMPOS, I. C., DO CARMO, F. F., SILVINO, G., PINTO, C. E. F. Fundão tailings dam failures: the environment tragedy of the largest technological disaster of Brazilian mining in global context. Perspectives in Ecology and Conservation, 2017.

CARVALHO, V. F.; ASSIS, J.; SERRÃO, E. A.; NUNES, J. M.; BATISTA, A. A.; BATISTA, M. B.; BARUFI, J. B.; SILVA, J.; PEREIRA, S. M. B.; HORTA, P. A. Environmental drivers of rhodolith beds and epiphytes community along the South Western Atlantic coast. Marine Enviromental Research, v. 154, p. 104827, fev. 2020.

CERASOLI, F.; IANNELLA, M.; D’ALESSANDRO, P.; BIONDI, M. Comparing pseudo-absences generation techniques in boosted regression trees models for conservation purposes: a case study on amphibians in a protected area. PLoS One, v. 12, n. 11, nov. 2017. https://doi.org/10.1371/journal.pone.0187589

CHEN, I-C.; HILL, J.; OHLEMULLER, R.; ROY, D.B.; THOMAS, C. Rapid range shifts of species associated with high levels of climate warming. Science, v. 333, n. 6045, p. 1024-1026, 2011.

CHEN, P. Y.; CHEN, C. C.; CHU, L.; MCCARL, B. Evaluating the economic damage of climate change on global coral reefs. Global Environmental Change, v. 30, p.12-20, jan. 2015. doi: 10.1016/j.gloenvcha.2014.10.011.

COPERTINO, M. S.; CREED, J. C.; LANARI, M. O.; MAGALHÃES, K.; BARROS, K.; LANA, P. C.; HORTA, P. A. Seagrass and submerged aquatic vegetation (VAS) habitats off the coast of Brazil: state of knowledge, conservation and main threats. Brazilian Journal of Oceanography, v.64(SPE2), p.53-80, 2016.

COPERTINO, M. S. et al. Zonas Costeiras. In: NOBRE, C.; MARENGO, J. (eds) Mudanças Climáticas em Rede: Um Olhar Interdisciplinar. Contribuições do Instituto de Ciência e Tecnologia para Mudanças Climáticas. São José dos Campos: INCT, 2017. p. 608.

COSTA, G. B.; RAMLOV, F.; DE RAMOS, B.; KOERICH, G.; GOUVEA, L.; COSTA, P. G.; BIANCHINI, A.; MARASCHIN, M.; HORTA, P. A. Physiological damages of Sargassum cymosum and Hypnea pseudomusciformis exposed to trace metals from mining tailing. Environmental Science and Pollution Research, v. 26, n. 36, p. 36486-36498, nov. 2019.

COUTINHO, R.; YAGINUMA, L. E.; SIVIERO, F.; DOS SANTOS, J. C. Q.; LÓPEZ, M. S.; CHRISTOFOLETTI, R. A.; MASI, B. $P$. Studies on benthic communities of rocky shores on the Brazilian coast and climate change monitoring: status of knowledge and challenges. Brazilian Journal of Oceanography, v. 64(SPE2), p. 27-36, 2016.CRAMER, W.; YOHE, G. W.; AUFFHAMMER, M.; HUGGEL, C.; MOLAU, U.; DA SILVA DIAS, M. A. A. F.; SOLOW, A.; STONE, D. A.; TIBIG, L.; LEEMANS, R.; SEGUIN, B.; SMITH, N.; HANSEN, G. Detection and attribution of observed impacts. In: Climate Change 2014 Impacts, Adaptation and Vulnerability: Part A: Global and Sectoral Aspects. 2015

CYBULSKI, J. D. et al. Coral reef diversity losses in China's Greater Bay Area were driven by regional stressors. Science Advances, v. 6, n. 40, p. eabb1046, 2020.

DARMARAKI, S.; SOMOT, S.; SEVAULT, F.; NABAT, P. Past variability of Mediterranean Sea marine heatwaves. Geophys. Res. Lett. v. 46, p. 9813-9823, 2019. doi: 10.1029/2019GL082933

DAVISON, I. R.; PEARSON, G. A. Stress tolerance in intertidal seaweeds. Journal of Phycology, n. 32, p.197-211, abr. 1996. doi:101111/j0022-3646199600197x.

DAYTON, P. K.; TEGNER, M. J.; EDWARDS, P. B.; RISER, K. L. Sliding baselines, ghosts, and reduced expectations in kelp forest communities. Ecological Applications, v. 8, n. 2, p.309-322, mai.1998. doi:10.2307/2641070.

DUARTE, L.; VIEJO, R. M. Environmental and phenotypic heterogeneity of populations at the trailing range-edge of the habitat-forming macroalga Fucus serratus. Marine Environmental Research, v.136, p.16-26, mai. 2018. doi:10.1016/j.marenvres.2018.02.004

EGGERT, A. Seaweed responses to temperature. In: WIENCKE, C.; BISCHOF, K. (Eds), Seaweed Biology. Springer Publishing, p. 47-66, 2012.

ELITH, J.; LEATHWICK, J. R.; HASTIE, T. A working guide to boosted regression trees. Journal of Animal Ecology, v. 77, p.802-813, abr. 2008. doi:101111/j1365-2656200801390x. 
ELFES, Cristiane T. et al. A regional-scale ocean health index for Brazil. PLoS One, v. 9, n. 4, p. e92589, 2014.

ELLIFF, C. I.; SILVA, I. R. Coral reefs as the first line of defense: Shoreline protection in face of climate change. Marine Environmental Research, v. 127, p. 148-154, 2017.

FERNANDES, G. W. et al. Deep into the mud: ecological and socio-economic impacts of the dam breach in Mariana, Brazil. Natureza \& Conservação, v.14, n. 2, p. 35-45, nov. 2016.

FIGUEIREDO, M. A. O.; TÂMEGA, F. T. S. Macroalgas marinhas Biodiversidade marinha da Baía da Ilha Grande Brasília: Ministério do Meio Ambiente, p 155-180. 2007

GALLON, R. K.; ROBUCHON, M.; LEROY, B.; LE GALL, L.; VALERO, M.; FEUNTEUN, E. Twenty years of observed and predicted changes in subtidal red seaweed assemblages along a biogeographical transition zone: inferring potential causes from environmental data. Journal of Biogeography, v. 41, n.12, p.2293-2306, ago. 2014. https:// doi.org/10.1111/jbi.12380

GBIF.org (26th September 2018). GBIF Occurrence Download. https://doi.org/10.15468/dl.1kuflx

GERHARDINGER, L. C.; GORRIS, P.; GONÇALVES, L. R.; HERBST, D. F.; VILA-NOVA, D. A.; DE CARVALHO, F. G.; GLASER, M.; ZONDERVAN, R.; GLAVOVIC, B. C. Healing Brazil's Blue Amazon: The Role of Knowledge Networks in Nurturing Cross-Scale Transformations at the Frontlines of Ocean Sustainability. Frontiers of Marine Science, v.4, jan. 2018. doi: 10.3389/fmars.2017.00395

GIANNI, F.; BARTOLINI, F.; AIROLDI, L.; BALLESTEROS, E.; FRANCOUR, P.; GUIDETTI, P.; MANGIALAJO, L. Conservation and restoration of marine forests in the Mediterranean Sea and the potential role of Marine Protected Areas. Advances in Oceanography and Limnology, v.4, n.2, p.83-101, dez. 2013. doi:10.4081/aiol.2013.5338.

GIRIR, C.; OCHIENG, E.; TIESZEN, L. L.; ZHU, Z.; SINGH, A.; LOVELAND, T.; MASEK, J.; DUKE, N. Status and distribution of mangrove forests of the world using earth observation satellite data (version 1.3, updated by UNEP-WCMC). Global Ecology and Biogeography, v. 20, p.154-159, 2011. doi:10.1111/j.1466-8238.2010.00584.x. http://data. unep-wcmc.org/datasets/4.

GORMAN, D.; HORTA, P.; FLORES, A. A.; TURRA, A.; BERCHEZ, F.A. D. S.; BATISTA, M. B. VILLAÇA, R. C. Decadal losses of canopy-forming algae along the warm temperate coastline of Brazil. Global Change Biology, v. 26, n.3, p.1446-1457, mar. 2020. doi:10.1111/gcb.14956.

GOUVÊA, L. P.; SCHUBERT, N. MARTINS, C. D. L.; SISSINI, M.; RAMLOV, F.; RODRIGUES, E. R. D. O.; VARELA, D. A. Interactive effects of marine heatwaves and eutrophication on the ecophysiology of a widespread and ecologically important macroalga. Limnology and Oceanography, v. 62, n. 5, p.2056-2075, set. 2017. doi: 10.1002/Ino.10551.

GOUVÊA, L. P.; ASSIS, J.; GURGEL, C. F.; SERRÃO, E. A.; SILVEIRA, T. C.; SANTOS, R.; DUARTE, C. M.; PERES, L. M. C.; CARVALHO, V. F.; BATISTA, M.; BASTOS, E.; SISSINI, M. N.; HORTA, P. A. Golden carbon of Sargassum forests revealed as an opportunity for climate change mitigation. Science of The Total Environment, 138745. v. 719, ago. 2020

GRILLI, N. DE M.; XAVIER, L.Y.; JACOBI, P.R.; TURRA, A. Integrated science for coastal management: Discussion on a local empirical basis. Ocean Coast Manag, v. 167, p.219-228, 2019. doi: 10.1016/j.ocecoaman.2018.10.009.

Gurgel, C. F. D., Camacho, O., Minne, A. J., Wernberg, T., \& Coleman, M. A. Marine heatwave drives cryptic loss of genetic diversity in underwater forests. Current Biology. v.30, p.1199-1206, 2020. doi.org/10.1016/j. cub.2020.01.051

HALPERN, B. S. et al. Spatial and temporal changes in cumulative human impacts on the world's ocean. Nature communications, v. 6, n. 1, p. 1-7, 2015.

HALPERN, B. S. Building on a Decade of the Ocean Health Index. One Earth, v. 2, n. 1, p. 30-33, 2020.

HANISAK, M.D.; SAMUEL, M.A. Growth rates in culture of several species of Sargassum from Florida, USA. Hydrobiologia, v. 151-152, p. 399-404, 1987. doi:10.1007/BF00046159. 
HATJE, V.; PEDREIRA, R. M.; DE REZENDE, C. E.; SCHETTINI, C. A. F.; DE SOUZA, G. C.; MARIN, D. C.; HACKSPACHER, $P$. C. The environmental impacts of one of the largest tailing dam failures worldwide. Scientific reports, v. $7, n$. 1, p. 1-13. set. 2017.

HIRAISHI, T., KRUNG, T., TANABE, K., SRIVASTAVA, N., BAASANSUREN, J., FUKUDA, M., TROXLER, T. G. Supplement to the 2006 IPCC guidelines for national greenhouse gas inventories: Wetlands. IPCC, Switzerland, 2014.

HOEGH-GULDBERG, O. et al. (eds). Climate Change 2014: Impacts, Adaptation, and Vulnerability. Part B: Regional Aspects. Contribution of Working Group II to the Fifth Assessment Report of the Intergovernmental Panel on Climate Change. Cambridge University Press, Cambridge, United Kingdom and New York, NY, USA, p.1655-1731, 2014.

HORTA, P. A. et al. Evaluation of impacts of climate change and local stressors on the biotechnological potential of marine macroalgae - A brief theoretical discussion of likely scenarios. Brazilian Journal of Pharmacognosy, v. 22, n. 4, p.768-774, jun. 2012. doi:10.1590/S0102-695X2012005000085.

HORTA, P. A., RIUL, P., AMADO FILHO, G. M., GURGEL, C. F. D., BERCHEZ, F., NUNES, J. M. D. C. \& SISSINI, M. Rhodoliths in Brazil: Current knowledge and potential impacts of climate change. Brazilian Journal of Oceanography, v. 64(SPE2), p. 117-136, 2016. doi.org/10.1590/S1679-875920160870064sp2

HORTA, P. A.; GURGEL, C. F. D.; RORIG, L. R.; PAGLIOSA, P.; RODRIGUES, A. C.; FONSECA, A.; BUCKERIDGE, M. Climate change feeds climate changes. Int J Hydro, v.2, n.1, p.61-62, 2018.

JACOBUCCI, G. B.; LEITE, F. P. P. Depth distribution and seasonal fluctuations of vagile macrofauna associated with Sargassum cymosum C Agardh at Lázaro beach, Ubatuba, São Paulo, Brazil. Revista Brasileira de Zoologia, v. 19, n. 1, p. 87-100, jul. 2002. doi:10.1590/S0101-81752002000500004

JAYATHILAKE, D.R.M.; COSTELLO, M.J. A modelled global distribution of the seagrass biome. Biological Conservation, v. 226, p. 120-126, out. 2018.

JUeterboCK, A.; TYBerghein, L.; VerbRUGGEN, H.; COYER, J. A.; OlSEN, J. L.; HOARAU, G. Climate change impact on seaweed meadow distribution in the North Atlantic rocky intertidal. Ecology and evolution, v.3, n.5, p.1356-1373, abr. 2013. https://doi.org/10.1002/ece3.541

KERR, R.; DA CUNHA, L. C.; KIKUCHI, R. K. P.; HORTA, P. A.; ITO, R. G.; MÜLLER, M. N.; ORSELLI, I. B. M.; LENCINAAVILA, J. M.; DE ORTE, M. R.; SORDO, L.; PINHEIRO, B. R.; BONOU, F. K.; SCHUBERT, N.; BERGSTROM, E.; COPERTINO, M. S. The Western South Atlantic Ocean in a High-CO2 World: Current Measurement Capabilities and Perspectives. Environmental Management, v.57, p. 740-752, 2016. doi: 10.1007/s00267-015-0630-x.

KOCH, M.; BOWES, G.; ROSS, C.; ZHANG, X-H. Climate change and ocean acidification effects on seagrasses and marine macroalgae. Global Change Biology, v. 19, p.103-132, 2013. doi: 10.1111/j.1365-2486.2012.02791.x.

$\mathrm{KOERICH}, \mathrm{G}$. et al. How experimental physiology and ecological niche modelling can inform the management of marine bioinvasions? Science of The Total Environment, v. 700, p. 134692, 2020.

Kronik, J.; Verner, D.; Mearns, R.; Norton, A. The role of indigenous knowledge in crafting adaptation and mitigation strategies for climate change in Latin America. Social Dimensions of Climate Change, 145, 2010. doi. org/10.1596/978-0-8213-7887-8

LAURIE, W. A. Effects of the 1982-83 El Niño-Southern Oscillation event on marine iguana (Amblyrhynchuscristatus Bell, 1825) populations on Galápagos. Elsevier Oceanography Series, v. 52, p. 361380, 1990.

LEÃO, Z. M., KIKUCHI, R. K., FERREIRA, B. P., NEVES, E. G., SOVIERZOSKI, H. H., OLIVEIRA, M. D., ... \& JOHNSSON, R. Brazilian coral reefs in a period of global change: A synthesis. Brazilian Journal of Oceanography, 64(SPE2), 97-116. 2016.

LEYBA, I. M., SOLMAN, S. A., \& SARACENO, M. Trends in sea surface temperature and air-sea heat fluxes over the South Atlantic Ocean. Climate Dynamics, 53(7-8), 4141-4153. 2019. 
LI, J. LIU, YINGCHAO, LIU, YAN, WANG, Q., GAO, X., GONG, Q. Effects of temperature and salinity on the growth and biochemical composition of the brown alga Sargassum fusiforme (Fucales, Phaeophyceae). J. Appl. Phycol. v.31, p.3061-3068, 2019. https://doi.org/ 10.1007/s10811-019-01795-9.

LIMA, F. P.; RIBEIRO, P. A.; QUEIROZ, N.; HAWKINS, S. J.; SANTOS, AM. Do distributional shifts of northern and southern species of algae match the warming pattern? Global Change Biology, v.13, n.12, p. 2592-2604, dez. 2007. doi:101111/j1365-2486200701451x.

MACÁRIO, E.; REIS, L. COVID-19, dívida pública e crise de financiamento de ciência e tecnologia no Brasil. Auditoria Cidadã, 2020.

MAGALHÃES, K. M. et al. Oil spill+ COVID-19: A disastrous year for Brazilian seagrass conservation. Science of The Total Environment, p. 142872, 2020.

MAGRIS, R. A.; GRECH, A.; PRESSEY, R. L. Cumulative human impacts on coral reefs: assessing risk and management implications for Brazilian coral reefs. Diversity, v. 10, n. 2, p. 26, abr. 2018.

MAGRIS, R. A.; MARTA-ALMEIDA, M.; MONTEIRO, J. A.; BAN, N. C. A modelling approach to assess the impact of land mining on marine biodiversity: Assessment in coastal catchments experiencing catastrophic events (SW Brazil). Science of The Total Environment, v. 659, p.828-840, abr. 2019.

MAGRIS, R. A. et al. A blueprint for securing Brazil's marine biodiversity and supporting the achievement of global conservation goals. Diversity and Distributions. 2020. doi.org/10.1111/ddi.13183

MANSILLA, M. A. Q.; PEREIRA, S. M. Variação temporal da abundância e composição específica da macroflora associada a uma população de Sargassum (Fucophyceae) do litoral sul de Pernambuco, Brasil. Boletim de Botânica da Universidade de São Paulo, p. 271-276, 1998. doi: 10.2307/42871503.

MARENGO, J. A.; CUNHA, A. P.; SOARES, W. R.; TORRES, R. R.; ALVES, L. M.; DE BARROS BRITO, S. S.; CUARTAS, L. A.; LEAL, K.; RIBEIRO NETO, G.; ALVALÁ, R. C. S.; MAGALHAES, A. R. Increase Risk of Drought in the Semiarid Lands of Northeast Brazil Due to Regional Warming above $4{ }^{\circ} \mathrm{C}$. Climate Change Risks in Brazil. Springer International Publishing, p. 181-200, 2019.

MARRONI, E. V.; ASMUS, M. L. Historical antecedents and local governance in the process of public policies building for coastal zone of Brazil. Ocean \& Coastal Management, v.76, p.30-37, mai. 2013. doi: 10.1016/j. ocecoaman.2013.02.011.

MARTA-ALMEIDA, M.; MENDES, R.; AMORIM, F. N.; CIRANO, M.; DIAS, J. M. Fundão Dam collapse: Oceanic dispersion of River Doce after the greatest Brazilian environmental accident. Marine pollution bulletin, v.112, n.1-2, p.359-364, nov. 2016.

MARTINS, C. D.; ARANTES, N.; FAVERI, C.; BATISTA, M. B.; OlIVEIRA, E. C.; PAGliOSA, P. R.; HORTA, P. A. The impact of coastal urbanization on the structure of phytobenthic communities in southern Brazil. Marine pollution bulletin, v. 64, n.4, p.772-778, 2012.

MARTINS, G.M.; ARENAS, F.; TUYA, F.; RAMÍREZ, R.; NETO, A.I.; JENKINS, S.R. Successional convergence in experimentally disturbed intertidal communities. Oecologia, v.186, n. 2, p. 507-516, 2018. doi:10.1007/s00442017-4022-1.

MARTINS, I. M.; GASALLA, M. A. Perceptions of climate and ocean change impacting the resources and livelihood of small-scale fishers in the South Brazil Bight. Climatic Change, v.147, p.441-456, fev. 2018. https:// doi.org/10.1007/s10584-018-2144-z

MÜLLER, R.; LAEPPLE, T.; BARTSCH, I.; WIENCKE, C. Impact of oceanic warming on the distribution of seaweeds in polar and cold-temperate waters. Botanica Marina, v. 52, n.6, p. 617- 638, dez. 2009. doi:101515/BOT2009080.

MUÑOZ, P. T.; SÁEZ, C. A.; MARTÍNEZ-CALLEJAS, M. B.; FLORES-MOLINA, M. R.; BASTOS, E.; FONSECA, A. ; GURGEL, C. F. D. ; BARUFI, J. B.; RÖRIG, L.; HALL-SPENCER, J. M.; HORTA, P. A. Short-term interactive effects of increased temperatures and acidification on the calcifying macroalgae Lithothamnion crispatum and Sonderophycus capensis. Aquatic Botany, v. 148, p. 46-52, ago. 2018. 
OLIVER, E. C. J., DONAT, M. G., BURROWS, M. T., MOORE, P. J., SMALE, D. A., ALEXANDER, L. V., et al. Longer and more frequent marine heatwaves over the past century. Nat. Commun, v.9, n.1324, 2018. doi: 10.1038/ s41467-018-03732-9

OPPENHEIMER, M.; CAMPOS, M.; WARREN, R.; BIRKMANN, J.; LUBER, G.; O’NEILL, B.; TAKAHASHI, K. Emergent Risks and Key Vulnerabilities. Climate Change 2014 Impacts, Adapt Vulnerability Part A Glob Sect Asp Contrib Work Gr II to Fifth Assess Rep Intergov Panel Climate Change. P.1039-1099, 2014. doi: 10.1017/CBO9781107415379.

PHILLIPS, J. A.; BLACKSHAW, J. K; BLACKSHAW, J. K. Extirpation of macroalgae (Sargassum spp) on the subtropical east Australian coast. Conservation Biology, v.25, n.5, p.913-921, set. 2011. doi: 10.1111/j.15231739.2011.01727.x.

PRADO, D. S.; SEIXAS, C. S.; BERKES, F. Looking back and looking forward: Exploring livelihood change and resilience building in a Brazilian coastal community. Ocean \& Coastal Management, v. 113, p.29-37, 2015a. doi: 10.1016/j.ocecoaman.2015.05.018.

PRADO, D. S.; SEIXAS, C. S.; BERKES, F. Looking back and looking forward: Exploring livelihood change and resilience building in a Brazilian coastal community. Ocean \& Coastal Management, v. 113, p.29-37, 2015b. doi: 10.1016/j.ocecoaman.2015.05.018.

QGIS Development Team (2019) QGIS Geographic Information System Open Source Geospatial Foundation Project http://qgisosgeoorg.

REYER, C. P. O. et al. Climate change impacts in Latin America and the Caribbean and their implications for development. Regional Environmental Change, v.17, p.1601-1621, 2017. doi: 10.1007/s10113-015-0854-6.

RIUL, P. Modelagem e distribuição de espécies bênticas. 2015. Tese de Doutorado. Universidade Federal de Santa Catarina, Florianópolis, Brasil.

ROSSI, P. et al. Austeridade fiscal e o financiamento da educação no Brasil. Educação\&Sociedade, v. 40, 2019.

ROY, J. et al. Sustainable Development, Poverty Eradication and Reducing Inequalities. In: MASSON-DELMONTE, V. et al. (Eds). An IPCC Special Report on the impacts of global warming of $1.5^{\circ} \mathrm{C}$ above pre-industrial levels and related global greenhouse gas emission pathways, in the context of strengthening the global response to the threat of climate change, sustainable development. p. 435-558, 2018.

R Development Core Team. R: A Language and Environment for Statistical Computing R Foundation for Statistical Computing, Vienna, Austria 2016.

RStudio Team, RStudio: Integrated Development for R RStudio, Inc, Boston, MA, 2016. URLhttp://wwwrstudiocom/.

SARAIVA, A.; LIMA, A. G. M.; ADAMS, C.; CERVONE, C. O. F.; OVERBECK, G. E.; QUEIROZ, H.; MENEZES, J. A.; GONÇALVES, L. R.; LONDE, L. R.; ELOY, L; CUNHA, M. C.; PRADO, R. B.; RAFAEL LEMBI, R. K.VIEIRA, S.; CONFALONIERU, U. E. C.; IMPERATRIZ-FONSECA, V. L.; AZEVEDO, S. M. F. O. Contribuições da Natureza para Qualidade de Vida. In: SEIXAS, C. S. (ed) Plataforma Brasileira de Biodiversidade e Serviços Ecossistêmicos. 2018.

SCHAEFFER-NOVELLI, Y., SORIANO-SIERRA, E. J., VALE, C. C. D., BERNINI, E., ROVAI, A. S., PINHEIRO, M. A. A., MARTINEZ, D. I. Climate changes in mangrove forests and salt marshes. Brazilian Journal of Oceanography, v. 64(spe2), p.37-52, 2016.

SCHERNER, F., VENTURA, R., BARUFI, J. B., \& HORTA, P. A. Salinity critical threshold values for photosynthesis of two cosmopolitan seaweed species: providing baselines for potential shifts on seaweed assemblages. Marine environmental research, v.91, p.14-25, 2012

SCHERNER, F.; HORTA, P. A.; DE OLIVEIRA, E. C.; SIMONASSI, J. C.; HALL-SPENCER, J. M.; CHOW, F.; NUNES, J. M. C.; PEREIRA, S. M. B. Coastal urbanization leads to remarkable seaweed species loss and community shifts along the SW Atlantic. Marine Pollution Bulletin, v. 76, p. 106-115, nov. 2013.

SHI, Lei. Mapping ecological trends by keywords in the last 20 years. PeerJ Preprints, 2019. 
SCHUBERT, N.; SALAZAR, RICH, W. A.; BERCOVICH, M. V.; ALMEIDA SAÁ, A. C.; FADIGAS, S. D.; SILVA, J.; HORTA, P. $A$. Rhodolith primary and carbonate production in a changing ocean: The interplay of warming and nutrients. Science of The Total Environment, v. 676, p. 455-468, 2019.

SEGURADO, P.; ARAÚJO, M. B.; KUNIN, W. E. Consequences of spatial autocorrelation for niche-based models. Journal of Applied Ecology, v.43, p.433-444, 2006.

SISSINI, M. N.; DE BARROS BARRETO, M. B. B.; SZÉCHY, M. T. M.; DE LUCENA, M. B.; OLIVEIRA, M. C.; GOWER, J.; MARTINELLI-FILHO, J. E. The floating Sargassum (Phaeophyceae) of the South Atlantic Ocean-likely scenarios. Phycologia, v.56, n.3, p.321-328, 2017. doi:10.2216/16-92.1.

SPALDING, M. D.; FOX, H. E.; ALLEM, G. R.; DAVIDSON, N.; FERDAÑA, Z. A.; FINLAYSON, M. A. X.; MARTIN, K. D. Marine ecoregions of the world: a bioregionalization of coastal and shelf areas. BioScience, v.57, n. 7, p. 573583, 2007.

SZÉCHY, M. D.; PAULA, E. D.; Padrões estruturais quantitativos de bancos de Sargassum (Phaeophyta, Fucales) do litoral dos estados do Rio de Janeiro e São Paulo, Brasil. Revista Brasileira de Botânica, v.23, n.2, p.121-132, 2000. doi:10.1590/S0100-84042000000200002.

SZÉCHY, M. T. M.; GALLIEZ, M.; MARCONI, M. I. Quantitative variables applied to phenological studies of Sargassum vulgare c Agardh (phaeophyceae-Fucales) from Ilha Grande Bay, state of Rio de Janeiro. Brazilian Journal of Botany, v.29, n.1, p 27-37, 2006. doi:https://doi.org/10.1590/S0100-84042006000100004

STENECK, R. S.; GRAHAM. M. H.; BOURQUE, B. J.; CORBETT, D.; ERLANDSON, J. M.; ESTES, J. A.; TEGNER, M. J. Kelp forest ecosystems: biodiversity, stability, resilience and future. Environmental Conservation, p.436-459, 2002.

TANAKA, K.; TAINO, S.; HARAGUCHI, H.; PRENDERGAST, G.; HIRAOKA, M. Warming off southwestern Japan linked to distributional shifts of subtidal canopy-forming seaweeds. Ecology and Evolution v.2, p. 2854-2865, 2012.

TEAGLE, H.; HAWKINS, S. J.; MOORE, P. J.; SMALE, D. A. The role of kelp species as biogenic habitat formers in coastal marine ecosystems. Journal of Experimental Marine Biology and Ecology, v.492, p.81-98, 2017. doi:10.1016/j.jembe.2017.01.017.

TEDESCO, E. C.; SEGAL, B.; CALDERON, E. N.; SCHIAVETTI, A. Conservation of Brazilian coral reefs in the Southwest Atlantic Ocean: a change of approach. Latin American Journal of Aquatic Research, v.45, n.2, 2017.

TYBERGHEIN, L.; VeRBRUgGEN, H.; PAULY, K.; TROUPIN, C.; MINEUR, F; DE CLERCK, O. Bio-ORACLE: a global environmental dataset for marine species distribution modelling. Global Ecology and Biogeography, v.21, p. 272-281, 2012. doi:101111/j1466-8238201100656x.

UNEP-WCMC, WorldFish Centre, WRI, TNC (2018). Global distribution of warm-water coral reefs, compiled from multiple sources including the Millennium Coral Reef Mapping Project. Version 4.0. Includes contributions from IMaRS-USF and IRD (2005), IMaRS-USF (2005) and Spalding et al. (2001). Cambridge (UK): UN Environment World Conservation Monitoring Centre. URL:http://data.unep-wcmc.org/datasets/1.

VERGÉS, A. et al. Tropicalisation of temperate reefs: implications for ecosystem functions and management actions. Functional Ecology, v. 33, n. 6, p. 1000-1013, 2019.

VIEJO, R. M.; MARTINEZ, B.; ARRONTES, J.; ASTUDILLO, C.; HERNANDEZ, L. Reproductive patterns in central and marginal populations of a large brown seaweed: drastic changes at the southern range limit. Ecography, v.34, p.75-84, 2011. doi:10.1111/j.1600-0587.2010.06365.x.

WEATHERDON, L. V.; MAGNAN, A. K.; ROGERS, A. D.; SUMAILA, U. R.; CHEUNG, W. W. L. Observed and Projected Impacts of Climate Change on Marine Fisheries, Aquaculture, Coastal Tourism, and Human Health: An Update. Front Mar Sci, v.3, 2016: doi: 10.3389/fmars.2016.00048.

ZANETTI, V. B., DE SOUSA JUNIOR, W. C., \& DE FREITAS, D. M. A climate change vulnerability index and case study in a Brazilian coastal city. Sustainability, v.8, n.8, p.811. 2016. 